\title{
Constitutionalism: A Skeptical View
}

Jeremy Waldron

New York University School of Law, jeremy.waldron@nyu.edu

This paper can be downloaded free of charge from:

http://scholarship.law.georgetown.edu/hartlecture/4 


\section{Constitutionalism-A Skeptical View ${ }^{1}$}

Jeremy Waldron

\section{Introduction}

My title this afternoon refers to a certain skepticism I have about the political theory associated with the term "constitutionalism." I know "constitutionalism" is a term of approbation; we are all supposed to be constitutionalists now. But I think it is worth sounding a critical note or two. Apart from anything else, even supporters of constitutionalism should worry that, without an occasional live critic to contend with, their faith may become (in Mill's words) a dead dogma rather than a living truth, a superstition or prejudice clinging accidentally to a form of words that once conveyed something interesting and controversial. ${ }^{2}$

\section{The Weakest Meanings of "Constitutionalism"}

The potential for "constitutionalism" to degenerate into an empty slogan is exacerbated by the fact that the word is sometimes used in a way that conveys no theoretical content at all. Sometimes the term seems to means little more than the study of constitutions. There is a book edited by George Connor and Christopher

1 This lecture is a very substantial revision and expansion of Jeremy Waldron, "Constitutionalism -A Skeptical View" from Contemporary Debates in Political Philosophy (Thomas Christiano and John Christman eds., 2009), 267 (Wiley-Blackwell) 
Hammons called The Constitutionalism of American States, and what it is, is just a comparative study of state constitutions. ${ }^{3}$ Or when Akhil Amar writes about "unwritten American constitutionalism," 4 all he means is that there are parts of the US Constitution that are not in the written document. There is nothing wrong with this usage. "Con law" has two syllables; why not use the seven or eight syllables of "constitutionalism" to make the study of constitutions sound important?

Sometimes the term is just used to refer to a constitutional doctrine - like "living constitutionalism and originalist constitutionalism ${ }^{5}$ or, my least favorite label "comparative constitutionalism" to refer not to the comparative study of constitutions but to the invocation of foreign human rights and constitutional law for the purpose of guiding the application of our constitution. ${ }^{6}$ It's a practice that I favor ${ }^{7}$ and I want to say quite a bit about it in the second half of my lecture, where I'll suggest that the best arguments for the use of foreign law are not

3 The Constitutionalism of American States (George E. Connor and Christopher W. Hammons eds. 2008) University of Missouri Press, c2008

4 Akhil Reed Amar, America's Constitution, Written and Unwritten, 57 SYRACUSE L. REV. 267 (2007) at 269.

5 Lawrence B. Solum, District of Columbia v. Heller and Originalism, 103 Nw. U. L. Rev. 923

(2009), at _.

6 (Get cite for comparative constitutionalism.)

7 Cite to Storrs lectures 2007 and 2005 Harvard article. 
constitutionalist arguments at all, but anti-constitutionalist arguments (and none the worse for that).

\section{Constitutionalism as a Theory}

So: sometimes "constitutionalism" is just a pompous word for various aspects of con law or the study of constitutions. Still, the last two syllables - the "-ism" - should at least alert us to an additional meaning that seems to denote a theory or set of theoretical claims. Constitutionalism is like liberalism or socialism or scientism. It is perhaps worth asking what that theory is and, whether the claims it comprises are true or valid. ${ }^{8}$

The Oxford English Dictionary refers, in the second meaning it gives to the term, to an attitude or disposition - "[a]dherence to constitutional principles." A constitutionalist is one who takes constitutions very seriously and who is not disposed to allow deviations from them even when other important values are involved. "Constitutionalism" therefore refers to the sort of ideology that makes this attitude seem sensible. So I suppose this includes the claim that a society's constitution matters, that it is not

8 Cf. Walter Murphy's insistence in 87 Tex. L. Rev. 1303

Texas Law Review June, 2009 Symposium: What, If Anything, Do We Know About Constitutional Design? I. Theories of Constitutional Design DESIGNING A CONSTITUTION:

OF ARCHITECTS AND BUILDERS Walter F. Murphy that "Labeling a document "the constitution" does not thereby imbue it with any of the norms of constitutionalism" 1308.

9 Oxford English Dictionary online, op. cit. The instances given are "1871 Daily Tel. 2 Nov., They persuaded the King that Constitutionalism was his natural role" and "1889 Times 19 Feb. 9/2 The frigid and negative constitutionalism of M. Carnot." 
just decoration, that it has an importance that may justify making sacrifices of other important values for its sake.

\section{Particular and General Constitutionalism}

Such a view might have two aspects: (i) it may be the view that the principles of a particular constitution are important; or (ii) it may be the general view that constitutions as such are important.

If it is the first, then "constitutionalism" means different things in different settings. It will refer both to an Englishman's affection for parliamentary sovereignty and an American's affection for judicially enforced limitations on legislative authority. ${ }^{10}$ On the second approach, by contrast, we would try and look at what various constitutionalisms have in common, even when they chauvinistically celebrate differently-shaped arrangements. Roger Scruton's definition of the term in his Dictionary of Political Thought is helpful as an example of (ii): he defines "constitutionalism" as the advocacy of constitutional government, i.e. of "government channeled through and limited by a constitution." "11 On this view, a constitutionalist is one who thinks it important for government to be organized through and

10 A.V. Dicey, Introduction to the Study of the Law of the Constitution, Eighth edition of 1915 (Indianapolis: Liberty Classics, 1982), p. 386, uses "constitutionalism" in this sense when he writes that "the aim of Australian statesmen has been to combine ... ideas borrowed from the federal and republican constitutionalism of the United States, ... with ideas derived from the Unitarian and monarchical constitutionalism of England."

11 Roger Scruton, A Dictionary of Political Thought (London: Macmillan 1982), p. 94. 
constrained by a set of constitutional rules; such a person will be opposed, for example, to various forms of absolutism (in the technical sense of "absolutism"), ${ }^{12}$ because that seems to involve repudiating the idea of rules limiting government at the highest level. Despite the differences between (say) English and American constitutionalism, we might say that constitutionalists in both countries celebrate and advocate forms of political structuring that limit the power of government in various ways. Some of these forms are similar (like federalism); some of them are different (like the more extensive provision for judicial review of legislation in the United States). But the idea of using formally articulated structure to constrain government is held in common by the two sets of constitutionalists, and it may be contrasted, on the one hand, with the older English view that governments are best restrained by an unarticulated ethos of moderation - "Not cricket, old boy"and, on the other hand, by the absolutist conviction that it may not be appropriate to try to limit government at all.

\section{Explicit and Implicit Constitutions}

12 As in "Princeps ab legibus solutus." The best known version of absolutism is that of Thomas Hobbes in Leviathan, ed. Richard Tuck (Cambridge: Cambridge University Press, 1996), Chs. 18 and 26. 
But maybe these are false contrasts. Perhaps we ought to say that every stable system of government has a constitution, if by a constitution we mean a set of fundamental rules establishing the way governmental powers are exercised, who exercises them, what their jurisdiction is, how laws are made and changed, and so on. ${ }^{13}$ So the British and the Israelis have a constitution just as much as the Americans and the Australians; the rules just exist in a different form. On this account, even dictatorship has a constitution; its constitution may differ from that of a system of parliamentary sovereignty; it may differ from a republican system of checks and balances; but it is still a constitution. ${ }^{14}$

According to this line of thought, if governance were imaginable without a constitution, it would have to be as the adventitious persistence of traditional ways of doing things without any consciousness of them as rules, But even then some would say that these ways of doing things can be identified as constitutional norms at least by outsiders, even if it doesn't occur to participants to think about them in these terms. When Alexander Hamilton remarked at the very beginning of The Federalist Papers that

$13 \mathrm{Cf}$. Aristotle, Politics, Book IV: "[a] constitution is the organization of offices in a state, and determines what is to be the governing body...."

14 But compare the response of Paul J. Magnarella, "The Comparative Constitutional Law Enterprise," Willamette Law Review, 30 (1994) 509, at p. 510: "By definition, every state, even one with a dictatorship, has a constitution - a set of legal norms and procedures that structure its legal and governmental systems. ... In the absence of the ruling elite's commitment to limited governmental powers under the rule of law, a state may have a constitution without constitutionalism. In such a case, comparativists would label its constitution 'nominal,' rather than 'normative'." 
it seems to have been reserved to the people of this country, ...to decide ... whether societies of men are really capable or not of establishing good government from reflection and choice, or whether they are forever destined to depend for their political constitutions on accident and force ${ }^{15}$

he seemed to be assuming that countries whose systems of governance are not established by reflection and choice do still have constitutions.

\section{Constitutionalism and Written Constitutions}

Is constitutionalism the celebration of written constitutions? It depends a bit what you mean by "written." Is it written-ness as opposed (say) to customary or is it concentration of all or most constitutional norms in one single canonical document? The UK is to a large extent written in the former sense, if you count the Bill of Rights of 1689, the Act of Union of 1707, the European Communities Act of 1971, the Human Rights Act of 1998, and the various Representation of the People Acts from 1918 to 2000. It is not concentrated in a single document, but I am not sure why a constitutionalist should think that this matters.

It is sometimes said that the main advantage of putting one's constitution into writing is that it establishes its authority as higher

15 Alexander Hamilton, John Jay, and James Madison, The Federalist, edited by George W. Carey and James McLellan (Indianapolis: Liberty Fund, 2001), p. 1. 
law, making it enforceable by the judiciary. This is what Justice Marshall said in Marbury v Madison:

[A]ll those who have framed written constitutions contemplate them as forming the fundamental and paramount law of the nation, and consequently the theory of every such government must be, that an act of the legislature repugnant to the constitution is void. This theory is essentially attached to a written constitution.... ${ }^{16}$

On its face, this is an implausible argument. The written-ness of a constitution is compatible with its being treated as ordinary legislation, like the New Zealand Constitution Act of 1986. Or it is compatible with it being treated merely as a piece of paper, with little legal effect, like the Soviet Constitution of 1936. On the other hand, judicial review of legislation can be thought legitimate even where the relevant provision of higher law is unwritten; or at least that was the position of Sir Edward Coke in Dr. Bonham 's case, ${ }^{17}$ which many American constitutionalists take seriously even if most English lawyers have never heard of it.

16 Marbury v. Madison 5 U.S. 137 (1803), at 177.

17 Dr. Bonham's case 8 Co. Rep. 114 (Court of Common Pleas [1610]): “And it appears ... that in many cases, the common law will control acts of parliament, and sometimes adjudge them to be utterly void: for when an act of parliament is against common right and reason, or repugnant, or impossible to be performed, the common law will control it, and adjudge such act to be void...." 
It is often said that individual rights and rules restraining government are insecure unless they are laid down in the terms of a written constitution. One is reminded of Walton Hamilton's ironic definition: "Constitutionalism is the name given to the trust which men repose in the power of words engrossed on parchment to keep a government in order." ${ }^{18}$ One would have thought that Americans might have taken on board the caustic observations of James Madison and Alexander Hamilton on "parchment barriers" as a "greatly overrated" form of security. ${ }^{19}$ But no; we persist with our faith that bullets cannot pass through paper.

But anyway, security is not the only virtue that can be claimed for written-ness. Other claims are more plausible: one is that written-ness allows the constitution to have a palpable presence in the polity. Hannah Arendt said that, in America, it was important that the Constitution be "a tangible worldly entity,"

18 Walton H. Hamilton, Constitutionalism, in 4 ENCYCLOPEDIA OF THE SOCIAL SCIENCES 255 (Edwin Seligman and Alvin Johnson eds., 1931), cited in Richard S. Kay, American Constitutionalism, in Constitutionalism: PhilosophicAl Foundations 16 (Larry Alexander ed., 1998) at p. 16

19 For Madison, see FEDERALIST \# 48: "Will it be sufficient to mark, with precision, the boundaries of these departments, in the constitution of the government, and to trust to these parchment barriers against the encroaching spirit of power? This is the security which appears to have been principally relied on by the compilers of most of the American constitutions. But experience assures us, that the efficacy of the provision has been greatly overrated; and that some more adequate defense is indispensably necessary for the more feeble, against the more powerful, members of the government." For Hamilton, see FEDERALIST \# 73: "The propensity of the legislative department to intrude upon the rights, and to absorb the powers, of the other departments, has been already suggested and repeated; the insufficiency of a mere parchment delineation of the boundaries of each, has also been remarked upon; and the necessity of furnishing each with constitutional arms for its own defense, has been inferred and proved." See also FEDERALIST \# 20, on the hapless inefficacy of the parchment on which the Belgic constitution is written. 
an endurable objective thing, which, to be sure, one could approach from many different angles and upon which one could impose many different interpretations, ... but which nevertheless was never a subjective state of mind, like the will. $^{20}$

This may be particularly important when constitutional arrangements are being considered and debated. A set of implicit rules is very hard to reflect upon in any coherent way among a large number of people. That's always been the frustrating thing about the unwritten aspects of the U.K. constitution, i.e., the aspects that consist of custom, convention, or undertstandings rather than statute law: the subject-matter is constantly shifting under one's gaze and the line between a normative provision of the constitution in this sense and a normative view about what the provisions of the constitution ought to be is a subject of constant equivocation. Deliberation can seem futile unless it is focused on a text which can serve as a focal point (even an imperfect focal point) for debate - a written text, by which issues are separated, and on which amendments may be registered. ${ }^{21}$

I do not want to quarrel with this aspect of constitutionalism. But I would enter two caveats.

20 Hannah Arendt, On Revolution (Harmondsworth: Penguin Books, 1973), p. 157.

21 I have argued this point for textual law generally in Jeremy Waldron, Law and Disagreement (Oxford: Clarendon Press, 1999), pp. 69-87. 
First, what is important is that written-ness should facilitate reflection, not stymie it with a sort of fetishism of either the written text itself or its interpretation. Once a text starts to be venerated, the words and the phrasing sometimes take on a life of their own, becoming a sort of obsessive catch-phrase for expressing certain underlying substantive concerns in a way that makes it difficult to focus on what is really at stake..$^{22}$ Also, with a written constitution as their battlefield, lawyers and judges are likely to be heavily distracted in their discussions by side-arguments about interpretive theory, and these abstract interpretive debates can sometimes crowd out serious arguments focused on the merits of the question under discussion, whether it is abortion, or affrmataive action, or campaign finance reform

Secondly, what is important is not just that there should be some form of conscious and explicit reflection on constitutional arrangements, but that this should be the work of the people whose society is to be governed by these arrangements. Notice how the two caveats go together. For many self-styled constitutionalists, especially in America, reflection and choice is a matter of history, often quite distant history - a matter for "the Framers" not for current politics. Our interpretations are driven by their debates.

22 (For example, in assessing American social and economic legislation in the early years of the twentieth century, was it really worth spending so much energy discussing whether "due process" can be substantive?) 
From this perspective, the value of the written text is the way the venerable calligraphy of the eighteenth-century endues the rules with an aura of ancestral authority. That seems to me to count against written-ness. The frustration I referred to earlier of having an unwritten constitution in (say) the United Kingdom is present frustration, not ancestral frustration. When I said that in a country without a written constitution, the ground is constantly shifting and it is hard to focus the debate about the fundamental structuring of governance, I meant the debate that is going on now, not the debate that took place between (I don't know) John Locke and King William-and-Mary. And the difficulty with the American model of textual fetishism is that it makes little contribution to normative debate about our governance arrangements here and now. I don't mean that we lack such a debate; I mean only that the reverence for the Framers' written text is not necessarily a way of facilitating it.

\section{Constitutionalism and Constraint}

I want to turn now to a more substantive aspect of constitutionalist ideology. Unlike, say, the Rule of Law, constitutionalism is not just a normative theory about the forms and procedures of 
governance. ${ }^{23}$ It is about controlling, limiting, and restraining the power of the state. Numerous books on constitutionalism make this clear in their titles. Scott Gordon's book on the subject is called Controlling the State: Constitutionalism from Ancient Athens to Today and András Sajó entitles his book Limiting Government: A Introduction to Constitutionalism. ${ }^{24}$ In a foreword to Sajó's book, Stephen Holmes writes that "[c]onstitutions are giant restraining orders motivated by a passion for avoidance. They are inevitably propelled by the desire to escape specific dangerous and unpleasant political outcomes." ${ }^{25}$ There are some more nuanced views. Cass Sunstein insists that limited government is just one of many principles associated with constitutionalism. ${ }^{26}$ But this goes against the general trend. "In all its successive phases," according to C.H. McIlwain, "constitutionalism has one essential quality: it is a legal limitation on government." ${ }_{27}$

\footnotetext{
23 Cf. Lon L. Fuller, The Morality of Law, Revised Edition (New Haven: Yale University Press, 1969), p. 96.

24 Scott Gordon, Controlling the State: Constitutionalism from Ancient Athens to Today (Cambridge: Harvard University Press, 1999) and András Sajó, Limiting Government: An Introduction To Constitutionalism (Budapest: Central European Press, 1999).

25 Sajó, op. cit., p. $\mathrm{x}$.

26 Cass R. Sunstein, “Constitutionalism after the New Deal,” Harvard Law Review, 101 (1987), 421, at pp. 434-36.

27 C.H. McIlwain, Constitutionalism Ancient and Modern (Ithaca: Cornell University Press, 1940), p. 24 (quoted by Gordon, op. cit., at p. 5). For most writers, constitutionalism equals constraint. They accept McIlwain's characterization or that of Carl Friedrich, who spoke of constitutionalism as "effective regularized restraint" on government. Carl J. Friedrich, Constitutional Government and Democracy: Theory and Practice in Europe and America 35-36 (4th ed. 1968)
} 
So: the assumption seems to be that the power of the state needs to be restrained, limited or controlled, lest it get out of hand. Constitutionalism (the ideology) is part of what Judith Shklar called "the liberalism of fear." ${ }^{28}$ The idea is that the concentration of power leads to its abuse and this is why the power-dispersing, the power-slowing, and the power-checking elements of constitutional structure are thought to be important.

All harmless stuff, right? Aren’t we all constitutionalists now, in this sense of constitutionalism? I wonder. Consider the terms that are used for this connection between constitutions and various forms of constraint. The most commonly used phrase is "limited government," but there is also talk of a connection between constitutionalism and "restraints" upon power and of constitutionalism as a doctrine of "control” (as in Scott Gordon's title "Controlling the State"). Now, taken analytically these phrases - "limited government," "restrained government," and "controlled government" - are not synonymous. They mean different things and they have different connotations in the theory of politics.

I'll begin with "control." The idea of controlling the state is not necessarily a negative or constraining idea. If I control a vehicle, I determine not only where it doesn't go, but also where it

28 Judith N. Shklar, "The Liberalism of Fear," in a collection of her essays, Political Thought and Political Thinkers, ed. Stanley Hoffman (Chicago: University of Chicago Press, 1998), 3. 
does go. we say it is important for the government as a whole to be controlled by the people. If the people want their government to ameliorate poverty, for example, it is the task of the constitution to provide institutions that can be controlled by this desire. Is that the sort of control that constitutionalists have in mind? I don't think so.

Restraint, by contrast, is definitely a negative idea: it is the idea of preventing the government from doing certain things. A "restraint" view proceeds on the basis that we can identify certain abuses that we want to avoid and we specifically prohibit them, building these prohibitions into the very document that constitutes governmental authority. Such prohibitions often take the form of rights - a right not to be tortured, a right to be free from interference with religious belief, and so on. The idea is that whatever the government affirmatively does, it must not do these things. Much of the popularity of modern constitutionalism is due to the fact that it seems to connect with human rights in this way. But that connection may be problematic for reasons that I'll explain at the end of my lecture.

For now, note that few constitutionalists rest content with these sorts of specific, piecemeal constraints. They also want to say that an important function of constitutions is to impose broader limitations on the sort of projects that governments can take on. 
Constitutionalists talk of "limited government" and they mean not just the avoidance of particular abuses, but a broader sense that many of the aspirations that governments - particularly democratic government - have sometimes had are per se illegitimate. Those who set up a democracy may be hoping for government intervention to ameliorate poverty, promote public health, and protect the environment. They know they are likely to face opposition from opponents who claim that this is none of the government's business. But now it seems that these opponents can phrase their opposition not just directly as a political position; but they can take on the mantle of constitutionalism, and add to their case against intervention that the interventionists do not take the constitutional dimension of governance seriously enough. With this sense of limitation, constitutionalism forfeits any claim to political neutrality; it is associated instead with conservative criticism of "big government." People talk of "laissez-faire constitutionalism," not just as one extreme form of constitutionalist ideology, but as a positioning of constitutionalism as such in favor of market provision, rather than state provision of many important goods and services. ${ }^{29}$

29 Cf. Linda Bosniak, "Constitutional Citizenship through the Prism of Alienage," Ohio State Law Journal, 63 (2002), 1285, at p. 1287. See also Douglas Sturm, "A Prospective View of the Bill Of Rights: Toward a New Constitutionalism," Journal of Law and Religion, 13 (1996-8) 27 , at pp. 29-30: "[C]onstitutionalism, a tradition of political theory and practice with which the idea of human rights is often associated, has the connotation of limited government. At one extreme, constitutionalism is linked with the concept of a laissez faire state..." 
Am I being too pedantic in this explication of the differences between control, limitation, and restraint? Surely all that is meant, when these terms are used loosely as synonyms of one another, is that a constitution consists of rules which regulate the actions and practices they apply to. But actually, no: I think the real position is that a great many self-styled constitutionalists are happiest with a situation in which no one looks too closely at the content of their position, so that they are free to capitalize on a certain looseness in the rhetoric, using the equivocations made possible by the juxtaposition of "control," "restraint," and "limit" to leverage the moderation of the person who believes that the government shouldn't be allowed to do just anything into an acceptance of the doctrine that it is unwise to allow the government to do too much.

It's not that I care particularly about the integrity of the constitutionalist tradition. It is a pompous heritage, and where pomposity comes in, equivocation is seldom far behind. I do worry, though, when similar moves are made in discussions about the rule of law. People say, the rule of law is about legal control of government, which it is; but some of them infer from this that therefore the rule of law is a doctrine of limited government, which it is not. Legal control of government, subjection of government decisions to the control of over-arching law can either limit or expand what government is doing. Consider for example section 
26 of the Constitution of South Africa, which requires the state to take reasonable legislative and other measures to achieve progressive realization of the right to adequate housing. If the government escapes legal control, it can neglect this priority and devote its attention and resources to a more limited agenda; but a government under law is required to expand its agenda to include this among its high priorities; and that is what the South African constitutional court decided in the Grootboom case. ${ }^{30}$ Yet I have heard people say that the Rule of Law is not interested in the enforcement of social and economic rights (such as section 26), that the enforcement of that provision or its legislative equivalents does not count as the Rule of Law because the Rule of Law is about legal control of government, which means limited government, not advocacy lawyering designed to expand the governmental agenda. And this feeds into a conservative strategy of appropriating the Rule of Law as an ideal for something like an IMF / World Bank agenda, which sees its aim as that of securing property rights and external investment against legislative encroachment. I have argued elsewhere that a respectable jurisprudence should have nothing to do with that conception of the Rule of Law, and I believe we also give no credit to the 
equivocating toggle between control of government and limited government that facilitates it.

In this connection, let me offer one other piece of pedantry. Constitutionalists sometimes say that their creed is simply that "there is a proper and improper use of state authority" and that it is the job of a constitution to "confine" the exercise of state authority to proper uses. ${ }^{31}$ Proper and improper: that's too options. But normative logic is tri-valent, not bivalent: actions are prohibited, permitted, or required. Three possible values, not two. Neglecting the third category - what is required, as opposed to permitted — can distort our analysis. Suppose we say, then - more accurately - that there are proper, improper, and required uses of state authority; then we will have to say that the job of the constitution is as much to ensure that the state does what it is required to do as to ensure that it is restrained from doing what is prohibited. The United States constitution - that peculiar and antiquated animal — does not have much in the way of affirmative requirements; and constitutional courts here have made a virtue of this in cases like Jackson v. City of Joliet 715 F2d 1200 (1983), with Judge Posner telling us and that " $[t]$ he men who wrote the Bill of Rights were not concerned that government might do too little for the people but that it might do too much to them.." ${ }^{32}$ Judge Posner may be

31 Kay, op. cit., 19.

32 Pin cite: 
right about our constitutional tradition, but I do think we should have much patience with an ideology that tries to foist this on everyone else in the world on the grounds that this is what constitutionalism as such requires.

\section{Empowerment and Authority}

What do constitutions do that constitutionalists (the ideologists of constitutionalism) downplay? First and foremost they empower: they establish institutions which allow people to cooperate and coordinate to pursue projects that they cannot achieve on their own. This is what Stephen Holmes and Sotirios Barber ${ }^{33}$ and others have called "positive constitutionalism."

We need an institution in which representatives of the community can assemble to debate and enact various measures to stand over and among us as laws. We need legislatures, large institutions, ${ }^{34}$ manned (peopled) in a certain way and invested with public authority so that they can act credibly in the name of us all. A constitution has to set up courts to administer and interpret its laws and resolve disputes in the name of the whole society; and it has to establish armed organizations to keep the peace in a society and to defend its interests, again in the name of the whole society; it has to empower institutions and personnel to deal with other

33 Sotirios A. Barber, Welfare and the Constitution 147-53 (2003).

34 Cite to JW, Large Legislatures. 
governments, similarly established in other countries, for purposes of peace and trade and war. The manner in which a constitution performs these affirmative constitutive tasks, the mode of operation it establishes for these institutions and the way it relates them to one another, are all crucial components of the establishment of public authority.

What I have just said is platitudinous and you may think that constitutionalists can be forgiven for brushing past these obvious points and cutting straight to the question of how the institutions set up for these purposes are to be limited and restrained. They may accept that constitutions are necessary in an affirmative way to constitute the power of the state. But their constitutionalism is something extra. In Sajó's words, “[c]onstitutions are about power; [but] a constitution impregnated with the ideas of constitutionalism is about limited power." ${ }^{35}$

Besides actually establishing centers of public power, constitutions lay down procedures for their operation, often quite formalistic procedures limiting not so much what can be done but how it is done. A constitutionalized politics is an articulate politics that moves deliberately and deliberatively from stage to stage and forum to forum, taking seriously the integrity of each part of (say) the law-making process or of other processes of political decision.

35 Sajó, op. cit., p. 2. 
I have in mind processes like bicameral legislation, the requirement of executive consent, and the articulate relation between legislature on the one hand, and the courts and agents of the executive who administer, interpret and enforce the laws. From a constitutionalist perspective, there is a tendency to think simplistically of devices like these: they are conceived just as brakes upon the law-making process, ways of slowing things down, points of possible resistance against oppressive legislation. Equally there is a tendency to think of the formal separation of powers between (say) legislature, executive, and judiciary simply as a way of diluting power and making it harder for it to be exercised. Everything is seen through the lens of restraint and limitation.

But constitutional structure need not be seen in that light: articulate process can be seen as a way of structuring deliberation and allowing multiple voices to be heard and securing multiple points of access for citizen input; bicameral arrangements can be seen as ways of empowering different voices in the community or voices in the community sampled for the purposes of representation in different ways; and the separation of powers can be seen - as Dicey saw it — as a way of taking seriously the integrity of what comes into existence as the result of a genuine 
legislative exercise. ${ }^{36}$ In general, we need to understand the importance of the way in which a constitution provides housing for the political activity of a society, establishing an in-between of furniture and formality so that public deliberation becomes a structured enterprise, allowing the views of one person to be brought articulately into relation with the views of others and facilitating the formation of well-thought-through, responsible and politically effective opinions. This is not primarily a matter of constraint ${ }^{37}$ it is a matter of what a constitution affirmatively makes possible out of what would otherwise be the loose and lurching and dangerous politics of the street. ${ }^{38}$

\section{Democracy: Constraint or Empowerment?}

Many of the points I have made apply most vividly to democracy, and the skeptical notes that I am sounding about constitutionalism as an ideology are democratic notes.

\footnotetext{
36 Cf. Dicey's account of separation of powers in his attempt to reconcile parliamentary sovereignty and the rule of law: Dicey, op. cit., pp. 268-73. That the legislature may not control what happens to an Act once it passes into the hands of the courts is not just a method for preventing oppression (by ensuring that the legislators themselves are subject to the force of what they have enacted), though it is that; it is also a way of marking something about what has been done in the legislature. By virtue of the legislature's solemn decision, what has been produced comes to have the special status of law; it is not just another governmental measure. And its handling after it leaves the legislature is the tribute paid to that fact through institutional articulation.

37 For an excellent account of how constraint on political participation may have, in the long run, an affirmatively empowering and structuring effect, see Samuel Issacharoff, "Fragile Democracies," Harvard Law Review, 120 (2007)

38 The themes I have mentioned here are particularly prominent in the constitutional theory of Hannah Arendt; see Jeremy Waldron, "Arendt's Constitutional Politics" in Dana Villa (ed.) The Cambridge Companion to Hannah Arendt (Cambridge: Cambridge University Press, 2001).
} 
When a constitutionalist thinks of democracy, his first thought is: How can we prevent democracy from degenerating into tyranny of the majority? What devices are available, what moves can be made, to restrain the tyrannical excesses to which democracies are endemically liable?

But of course there are prior questions that need to be attended to as well, questions of affirmative empowerment. How is the democracy to be constituted? What is to be the system of representation? What are to be the different democratic requirements of for different kinds of political office (the election of a head of the executive, for example, versus the election of a legislator; maybe even the election of judges)? How is the integrity of the electoral process to be guaranteed? And above all, dominating all of these questions: How is the central principle of political equality, which is the foundation of democracy, to be upheld and enforced?

I actually think there is an important contrast here between the constitution of power in democratic societies and the constitution of power in non-democratic societies. In nondemocratic systems of government, it is usually the task of the constitution to formalize the authority of those to whom, as it were, power comes naturally or who, as it happens, have been vested historically with power over a given society. The constitution of a 
democracy, by contrast, involves empowering those who would otherwise be powerless, the ordinary people who in most polities are the subjects not the agents of political power. The man whom Colonel Rainborough referred to as "the poorest he that is in England" is the hardest man to empower, because if things are left to themselves he will have no political power at all. ${ }^{39}$ If his empowerment is achieved, it is the achievement of a democratic constitution that has had to go out of its way to ensure that he has as much formal political authority as "the greatest he."

Also, it is not enough to give the people, equal political power; one has to maintain them in that status, because this equality is endemically liable to subversion from all sorts of directions. When one is dealing with millions of people, the maintenance of political equality requires considerable attention. It is something a political system has to work at, for there is a standing tendency to dilute or compromise or (if possible) to bypass the enfranchisement or effective representation of the common people. A effective democratic constitution requires us to pay attention to the surrounding phenomena of politics, such as the influence of wealth and other forms of social and economic power,

39 I am thinking of Colonel Rainborough's exclamation in1647 at Putney: "[T]ruly I think that the poorest he that is in England has a life to lead as the greatest he; and therefore truly, sir, I think it's clear that every man that is to live under a government ought first by his own consent to put himself under that government." ("The Debates at the General Council of the Army, Putney, 29 October 1647," in Andrew Sharp (ed.) The English Levellers (Cambridge: Cambridge University Press, 1998), p. 103.) 
to ensure that the political equality definitive of democracy remains a reality for all members of the society and not just an ideological decoration.

Imagine what our constitution would be like if it embodied an explicit and affirmative commitment to democratic values - a clause that read something like this (I'll call it the political equality clause):

Political equality clause: The maintenance of democracy and of political equality, including universal suffrage (without regard to race, sex, income, or wealth), and the securing of the fair value of individual votes in light of principle of political equality, shall be a paramount feature of this constitution. ${ }^{40}$

And imagine that Citizens United $v F C C^{41}$ came before the Court. We might imagine that case being decided quite differently, if the First Amendment restraints and limitations, which formed the actual basis of the Supreme Court's decision in that case, had been juxtaposed with a clause like this. As long as the First Amendment restraints are prominent and explicit while principles of democratic empowerment, such as the principle of political equality, have to

40 (The republican government clause in Article IV (4) comes close to the sort of thing I mean, even though it makes no specific reference to democracy as such - the Framer's being antidemocratic by inclination - and it has become defanged ever since Luther v. Borden, 48 U.S. 1 (1849).

41130 S.Ct. 876 (2010). 
be scrabbled together in makeshift form from the defunct republican government guarantee and perhaps from Article I (2), also the second clause of the $14^{\text {th }}$ Amendment, and from the terms of the $15^{\text {th }}, 17^{\text {th }}, 19^{\text {th }}$, and $26^{\text {th }}$ Amendments, then the balance is bound to be skewed, especially against a background of constitutionalist ideology which holds that the setting of explicit limits on government is immeasurably more important than democratic empowerment.

If anything, matters are in even worse shape than this. The problem is not just that constitutionalism neglects the task of democratic empowerment; constitutionalism takes democracy and the power assigned to ordinary people through elective and representative procedures as its natural enemy. One would think that a theory of politics devoted to imposing constraints upon the abuse of power would have in its sights all forms of tyranny, all forms of oppression. But again and again in the constitutionalist literature, one reads that it is the tyranny of the majority that constitutionalism is concerned to check, not tyranny in general. So, for example, we hear scholars talking of “constitutionalism's fundamental commitment to protect certain decisions from current 
majoritarian impulses"42 and describing constitutionalism as "at base, protection against the consequences of majoritarian power." ${ }_{43}$

I guess it is possible to imagine an alternative form of constitutionalism: scholars talk of "popular constitutionalism" or "democratic constitutionalism." ${ }_{44}$ I have nothing against such usages, though I have tried to sharpen the issues that I have been discussing by avoiding them. No doubt this has led to some exaggeration. No doubt a more moderate constitutionalism can be envisaged. (And no doubt all sorts of equivocations are imaginable by which the issues discussed in this part of the lecture can be fudged.) But I think it is worth setting out a stark version of the antipathy between constitutionalism and democratic or popular self-government, if only because that will help us to measure more clearly the extent to which a new and mature theory of constitutional law takes proper account of the burden of ensuring that the people are not disenfranchised by the very document that is supposed to give them their power.

\section{Popular Sovereignty}

\footnotetext{
42 Robert A. Schapiro, "Polyphonic Federalism: State Constitutions in the Federal Courts," California Law Review, 87 (1999), 1415, at p. 1438

43 Sandra Schultz Newman and Daniel Mark Isaacs, "Historical Overview of the Judicial Selection Process in the United States: Is the Electoral System in Pennsylvania Unjustified?" Villanova Law Review, 49 (2004), 1 at p. 16

44 See, e.g., Larry D. Kramer, The People Themselves: Popular Constitutionalism and Judicial Review (New York: Oxford University Press, 2004) and Frank I. Michelman, "What (if Anything) is Progressive- Liberal Democratic Constitutionalism?" Widener Law Symposium, 4 (1999), 181. See also Mark Tushnet, Taking the Constitution Away from the Courts (Princeton: Princeton University Press, 2000).
} 
One area where we find that constitutionalists are prepared to flirt with democratic ideas is in their conception of the proper authorship of a constitution. A constitution may be conceived as a set of constraints, but it is important that these be understood as constraints that in some sense we have imposed on ourselves, rather than had imposed on us from the outside. It is a product of popular sovereignty - "We the People...do ordain and establish this Constitution"-and its constraining power depends on that. So, for example, the U.S. Supreme Court in Marbury v. Madison began from the premise that "the people have an original right to establish, for their future government, such principles as, in their opinion, shall most conduce to their own happiness" and argued that a judicial power to strike down unconstitutional legislation was necessary to give effect to the "original and supreme will" of the people. ${ }^{45}$

Now admittedly it is not a very robust concession to democracy. Randy Barnett has suggested quite rightly that we should be careful about reading our own democratic commitments (if we have any) back into this phrase. ${ }^{46} \mathrm{At}$ its best, constitutionalism represents the power of past majorities over

45 Marbury v. Madison 5 U.S. 137 (1803), at 176.

46 See, e.g., Randy E. Barnett, The People or the State? Chisholm v. Georgia and Popular Sovereignty, 93 Va. L. Rev. 1729 (2007). 
present and future majorities. ${ }^{47}$ At worst, we have to acknowledge the logical possibility that the idea of the people having the right to establish their own form of government is logically quite compatible with their establishment of a non-democratic constitution or a heavily compromised or truncated form of democracy. ${ }^{48}$ For the American case, many constitutionalists are as comfortable talking about "the Framers" and their extraordinary virtue - which is a decidedly non-populist conception - as they are talking about popular sovereignty. They will scramble back to popular sovereignty if there is some question about giving constitutional constraints credentials that can stand up to the democratic credentials of the legislative acts they are supposed to strike down. But it is a thin and mostly unconvincing maneuver. Mostly what matters to them is actually not that the constraints were crafted in any literal sense by the people, but that they emerged - as a matter of self-determination in the new American republic, among those who were forming a new edifice of government having repudiated the colonial structures that had been imposed upon them. Constitutionalism is about self-determination; but self-determination is not necessarily a democratic idea.

47 Larry Alexander, "Constitutional Rules, Constitutional Standards, and Constitutional Settlement: Marbury v. Madison and the Case for Judicial Supremacy," Constitutional Commentary, 20 (2003), 369, at p. 373.

48 See Locke, op. cit., pp. 329-30 and 354-6, and Thomas Hobbes, De Cive: The English Version, ed. Howard Warrender (Oxford: Clarendon Press, 1983), pp. 37 and $131 \mathrm{ff}$. 


\section{2. "We the people..." and other models of restraint.}

Still even if "We the people..." is not a major concession to democratic principles, it plays an important role in the distinctive economy of constitutionalism, and it has a major impact on the way in which restraints on government are understood.

When I said earlier that constitutioanlists over-emphasize limits and restraints as functions of a constitution, I didn't mean to suggest that restraints were unimportant. I didn't mean to disparage the idea of specific restraints on government action. There are things that governments are capable of doing to those who fall into their power that we want, without question, to prohibit and restrain by law. You don't need examples, but I'll mention one that has concerned a lot of us over the past eight years: there is a consensus in the world that governments need to be restrained from torture, from authorizing or permitting torture, from any sort of complicity in torture, and indeed even using its coercive powers (e.g., its powers of deportation) to put people at risk of torture. These constraints need to be in place and, if they are in a constitutional document, well and good: that is a good base from which they can operate in a society that takes its constitutional document seriously. My only quibble is with a constitutionalist ideology that makes 
restraints like these or more general limitations on government into the essence of what constitutions are supposed to do. ${ }^{49}$

Apart from constitutionalism, there are a number of different ways in which restraints on government can be understood. I have in mind three or four different models.

(i) There is the constitutionalist model, which sees the imposition of specific restraints on government as a primary-if not the primary-function of constitutions. We are all familiar with the contrast between this model and a couple of other models associated with past and present practices in Westminster style democracies.

(ii) One of these is the legislative model, in which primary legislation is used to lay down limits on government. So, in New Zealand, there is something called the New Zealand Bill of Rights Act - a piece of legislation passed by an ordinary parliamentary majority in 1990, which now operates as a major focus for the conviction in New Zealand political culture that, even with a sovereign Parliament, the powers of the state are not unlimited. Another example is the UK Human Rights Act 1998, though that is

49 I suspect Ronald Dworkin is right when he says that it is a defining feature of American constitutionalism, and something it has contributed to constitutional theory generally in the world, that it is a good idea to have these prohibitions as part of the document that actually frames and empowers government in the first place. < get cite from Freedom's Law (That's the American model and the German model; though other countries use different structures - Canada, for example, and the United Kingdom.) But describing things in that way, flattering as it is to us in America, makes sense only on the assumption that the constitution into which these clauses are inserting is actually doing something by way of substantive empowerment. 
complicated by the fact that it also represents the domestication of a regional human rights instrument: the European Convention on Human Rights. (More of that in a moment.)

We, the people of the United States, think that the legislative model is defective in at least two respects. First, the legislation in question is not entrenched, at least in a formal sense; it is not formally established as higher law; in theory it could be overturned by any parliamentary majority determined to act against the letter or spirit of its provisions. (This is true as a formal matter, though whether it is true as a matter of political culture remains to be seen.) Secondly, we think this model is defective in not making provision, explicitly or implicitly, for strong judicial review of primary legislation. I have said almost everything I want to say about that concern elsewhere; I am a sworn enemy of judicial review, but I have sworn to myself that I would not talk about judicial review in this lecture!

(iii) A third model, also associated with Westminster-style democracies, involves reliance on a sense of restraint embedded in the heritage of ordinary common law and in the judiciary's sense of values associated generally with legality and natural justice. This has been important historically in Britain, under the influence of Albert Venn Dicey, who regarded it as a defining feature of the rule of law that 
the general principles of the constitution ([like] the right to personal liberty, or the right of public meeting) are with us the result of judicial decisions determining the rights of private persons in particular cases brought before the Courts; whereas under many foreign constitutions the security (such as it is) given to the rights of individuals results, or appears to result, from the general principles of the constitution. ... Our constitution, in short, is a judge-made constitution, and it bears on its face all the features, good and bad, of judgemade law.

I believe we are inclined to think that this is completely fragile and hopeless as a basis for restraint on the power of government, though it is worth noting first that Dicey actually associated the United States with Britain in this regard, saying that notwithstanding the written Bill of Rights, in fact the sense of restraint on government was also woven into the ordinary fabric of American law, and secondly_-looking for comparison not at American-style Bill of Rights but at Continental European style constitutions, he thought actually the British model was more resilient. ${ }^{50}$

\footnotetext{
50 "where the right to individual freedom is a result deduced from the principles of the constitution, the idea readily occurs that the right is capable of being suspended or taken away. Where, on the other hand, the right to individual freedom is part of the constitution because it is inherent in the ordinary law of the land, the right is one which can hardly be destroyed without a thorough revolution in the institutions and manners of the nation."
} 
OK - put those two models to one side: the legislative model of restraint and the common law model. The contrast between them and the first, the constitutionalist model is pretty clear.

(iv) Now consider a fourth model: I shall call it the human rights model. On this account, the primary mechanism for conveying a sense of specific restraint onto the actions of the state is human rights law, contained in multi-lateral conventions like the International Covenant on Civil and Political Rights (ICCPR) and in international humanitarian law the Geneva Conventions, as well as in more specific instruments like the Convention against Torture. By signature and ratification of these covenants, states pledge themselves not to violate certain specific human rights and devote themselves to the curbing and elimination of human rights abuses.

The interesting thing about this body of law is its uniformity or, to put it another way, its commonality. In the ICCPR, more than 160 countries have pledged themselves to the same set of restraints. Founded and constituted at different ways, this disparate array of states have adopted a common legal doctrine of things that it is not appropriate for a state to do. True there is a bit of raggedness around the edges of this uniformity, stemming partly from the reservations that particular states may make at the time of signature or ratification from particular provisions. (The US, for 
example, entered a very heavy reservation on the ICCPR's provision regarding hate speech.) $)^{51}$ But the principle of the thing is that these are human rights, rather than the rights of any particular people organized under any particular constitution. The covenant represents a commitment by each state party, but it is a joint as well as a several commitment: so that the covenant regime binds states together into a single system dedicated to the non-violation and promotion of human rights. ${ }^{52}$ Or, to look at it from the other side of the social contract - from the bottom up, as it were-it represents a commitment by the peoples of the world to insist from now on that we will be governed subject to these restraints, and that we will look out for each other in this regard.

Now, obviously we do not pursue this security through human rights law alone. Human rights law usually requires signatory states to incorporate the relevant restraints into their municipal law. Article 2 (2) of the ICCPR, for example, requires countries to make legal provision for rights at a national level. It says:

51 Article 20(2) of the international Covenant on Civil and Political Rights requires that "[a]ny advocacy of national, racial or religious hatred that constitutes incitement to discrimination, hostility or violence shall be prohibited by law." The US has said that does not accept any obligation to restrict rights to free speech, to the extent that it is protected by the Constitution and laws of the United States.

52 (I don't want to exaggerate this. The prime responsibility of states party to, say, the ICCPR is responsibility (under Article 2) for their own conduct not other countries' conduct. There is formal provision for states to complain about one another's rights violations under Article 41(1) of the ICCPR; but apparently it has never been used, and only 47 states have signed for participation in that facility. ALSTON AND STEINER, INTERNATIONAL HUMAN RIGHTS IN CONTEXT (2000), p. 739. 
Where not already provided for by existing legislative or other measures, each State Party to the present Covenant undertakes to take the necessary steps, in accordance with its constitutional processes ... to adopt such laws or other measures as may be necessary to give effect to the rights recognized in the present Covenant.

Sometimes this is done in their constitution; or the Article 2(2) obligation is accepted as satisfied because these rights have already been incorporated into a constitutional document, perhaps long ago. Sometimes it is done through a free-standing Bill of Rights, or a statutory one. Sometimes it is done through ordinary statute law: for example, the United States' anti-torture statute was enacted in order to discharge a similar obligation under the international Convention Against Torture.

The basic logic here - of dual positivization — is something that happens with many multi-lateral conventions. Here's an example. A number of countries enter into an aviation convention to secure standards of airline safety and flight paths etc in the world. The convention requires each country to enact a civil aviation statute mirroring the terms of the convention, and the idea is that these statutes will also look like each other, so that the effect of administering the separate statutes in their respective countries is to produce harmonization of airline practice around the world. 
I think the human rights model of restraint is supposed to work in a similar way. No doubt there is more room for local variance in the case of human rights law. There is not much room for margins of appreciation with flight paths! As I said, some of the national-level positivization will be a consequence of lawmaking years or centuries before the international standard was articulated. So there is some diversity among national-level formulations, and these can lead to some tensions, admirably explored in an article by my former Columbia colleague, Gerald Neuman on "Human Rights and Constitutional Rights: Harmony and Dissonance. ${ }^{.33}$ But neither the disparities nor the tensions seem to pose any insuperable obstacle to the emerging sense of a common global commitment to certain rights-based restraints on state power.

Bruce Ackerman has urged that we see this as the emergence of "world constitutionalism." ${ }_{54}$ In my view that is exactly the wrong way to look at it. True, at some times and in some countries human rights-based restraints have been incorporated into constitutional documents - some of them, as in the United States, antedating by a century or more the emergence of these

53 Gerald L Neuman, "Human Rights and Constitutional Rights: Harmony and Dissonance," 55 Stan. L. Rev. 1863 (2002-2003). See also See Philip Alston, A Framework for the Comparative Analysis of Bills of Rights, in Alston (ed.) PrOMOTING HuMAN Rights THROUGH BILLS OF Rights: COMPARATIVE PERSPeCtives (OUP, 1999).

54 Bruce Ackerman, The Rise of World Constitutionalism, 83 Va. L. Rev. 771, 779-80 (1997) 
commitments at the level of international law. And it is true, too, as my NYU colleague Philip Alston has put it, that the effort at the international level was encouraged by the fact that there were sufficient similarities among existing national-level protections, many of them in constitutional documents, to justify an inductive sense that it might be appropriate to articulate a single set of common standards at any international level..$^{55}$ Constitutional law - the constitutional law of individual nations - has played its part at both ends of this process. But that doesn't mean that the fourth model - the global commitment to human rights - reduces to the first model, the constitutionalist conception.

For there is this crucial difference between them. As I said a little while ago, constitutionalists accept—indeed they insist — that a country's constitution should be a product of national selfdetermination. It is for each country to give itself a constitution, and the constitution that country A gives itself is not necessarily the same - certainly it does not have the same basis of authorityas the constitution that country B gives itself. They have their framers; we have ours. And the restraints on government in our constitution are to be understood in the first instances as acts of our framers, whatever their content or their wording may have in

55 (Alston, p. 11) Cites to Sieghart, The InTERnational LAW of Human Rights, xix. 
common with restraints on government in the constitutions of the countries to our north or to our south.

No one denies that there is a lot of imitation and boilerplating - and (frankly) sheer copying - between the constitutions of different countries. For example, the American Eighth Amendment and the Canadian Charter of Rights and Freedoms reproduce, more or less exactly, the words of the English Bill of Rights of 1689 on the issue of excessive, cruel and unusual punishment. Similarly the cruelty and inhumanity of punishment is made an issue in the ICCPR and in the numerous national bills of rights (like New Zealand's and South Africa's) that draw from it. This copying is understandable. For one thing, constitutionalism per se is supposed to be a theory available for use by any country in framing its fundamental law; it is a proselytizing faith and remarkably successful in its evangelization. Countries learn from each other in the framing of a constitution; sometimes countries send out experts in constitution-framing to advise emerging democracies; sometimes a constitution is imposed by one country on another prior to being autonomously adopted as an exercise in self-determination; and sometimes commonalities arise because of the obligations of dual positivization under international law that we have just been talking about. So there is a lot in common. 
But still there is a difference between seeing this common material — restraints on government — in a global light, as the fulfillment of a common obligation to incorporate human rightsbased restraints, and seeing the restraints in a constitutionalist light, as a self-determining decision by local framers-a welladvised decision, no doubt, but ultimately self-determining in each case.

The difference has become apparent to us in the United States in the controversy over the citation of foreign law. What makes the citation of foreign law seem sensible to some people is not just a desire to march in lock-step with the Europeans, but an awareness of non-accidental similarities in the way our various restraints on government are formulated. Maybe guidance can be drawn from the way in which other countries work with this language; or it may be suggested that we should play our part in ensuring some consistency in the way in which a common formula of restraint is interpreted around the world. From the perspective of the human rights model of restraint, nothing is more natural. After all the aim of putting the provision into national law is to give effect around here to a global conviction that government ought to be limited in a certain way. The fact that the provision is in our constitution is not itself a reason for ignoring or repudiating the global aspect of our commitment to this restraint, any more than the fact that 
something about airline navigation standards is contained in our

Civil Aviation statute is a reason for ignoring the global dimension of the matter.

But from the constitutionalist perspective this will seem something of an affront. Even though he thinks that restraining government is the essence of constitutionalism, it is also important to the constitutionalist that these restraints be viewed as essentially and crucially the product of a given nation's own constitutionmaking: our constitution, ours. And so you get statements like Justice Scalia's in Thompson v Oklahoma, interpreting provisions, which as a matter of fact echo the commitments of many other countries, insisting nevertheless that " $[\mathrm{w}] \mathrm{e}$ must never forget that it is a Constitution for the United States of America that we are expounding." ${ }^{56}$ And you get all the fury that erupted in the wake of the Supreme Court's decision in Roper v Simmons in 2005, the juvenile death penalty case, in which Justice Kennedy and others thought it relevant to refer to the practices of other nations, and to the fact that since 1990 the United States was alone among the democracies in the world in admitted to executing people for offences committed when they were children. ${ }^{57}$ Everyone flew into a fury, when the Court said that '[i]t is proper that we acknowledge

56 Thompson v. Oklahoma, 487 U.S. 815 (1988), at 830-1 (Stevens J, for the Court). Ibid., 869 (Scalia J., dissenting).

57 The others were Iran, Pakistan, Saudi Arabia, Yemen, Nigeria, Dem. Republic of Congo, and China. 
the overwhelming weight of international opinion against the juvenile death penalty." Justice Scalia blew up: he said "the basic premise of the Court's argument - that American law should conform to the laws of the rest of the world - ought to be rejected out of hand." And outside the court, there were ferocious newspaper editorials, death threats against some of the justices, ugly talk of impeachment, and legislation was introduced in the Congress which would prohibit any reliance by a federal court on foreign legal materials other than English cases decided before 1776. Such fury! - when all the court was doing was noticing a disparity between our sense of restraints on government and what other countries have done with very similarly formulated restraining provisions.

I once tried to convince Justice Scalia that as a good textualist he should be interested in what other countries have made of the same text like "cruel and unusual" in Canada. He looked at me as though I was mad. For him the crucial thing is not the text of the restraint per se, but the text in the mouths of the particular set of constitution-framers who have used it, and he is confident that there is nothing we can learn from Canadian judges interpreting the words of Canadian framers that would help us 
interpret the same words understood as emanating from framers in Philadelphia two centuries earlier..$^{58}$

As I have said, it seems to matter for the constitutionalist that the restraints imposed by a constitution upon government should be the upshot of something like an exercise of popular sovereignty, or at least the upshot of a process endogenous to the political system in which the constraints are supposed to operate. If people have thought it important to have these constraints, it is important that it be we, the people, with our constraints. If the restraints are a product of history, it is important that it be a product of our history. It simply doesn't matter, from this perspective, if our constitutional restraints are out of sync. with constitutionalist restraints elsewhere: it doesn't matter if our restraints are more severe on government than other countries' (on the matter of free speech for example) or less severe (on matters like the death penalty). How could it matter? - it's our constitution, not theirs.

That at least is what many American constitutionalists say. And presumably the general constitutionalist position is that every people should feel this way about the restraints on government imposed in their respective constitutions. Restraint is important, but not so important as to trump constitutional self-determination.

58 And this even without anything remotely like a showing that the meaning of the words - as opposed to the political and humanitarian views of the respective framers- have changed. In fact as any dictionary will tell you, the words "cruel" and "unusual" have not changed their meaning since the eighteenth century, though our dispositions to apply them to various practices have. 


\section{Conclusion}

Well, there you have it: some reflections - some critical reflections on the political theory we call "constitutionalism." I have argued that constitutionalism is not just an interest in constitutions, nor is it simply a recommendation that a country's constitutional arrangements should be put in written form. I have argued that it comprises a commitment to fundamental self-determination (in some versions a commitment to popular sovereignty) along with an ideology of restrained and limited government which in many ways is quite uneasy with or hostile to the idea of popular government and quite willing to neglect or sideline important tasks such as democratic empowerment.

The two views make an odd couple and I am not sure what motivates the combination. Why, if you believe that restraint or limitation, as such, is the name of the game, does it matter so much who imposed the restraints? Why the fury, why the jealous possessiveness, why the crocodile tears about the affront to democracy, when democracy has never been high in the pantheon of constitutionalism? I'll be interested in your answers? 